\title{
Control Efficacy of Bacillus velezensis AFB2-2 against Potato Late Blight Caused by Phytophthora infestans in Organic Potato Cultivation
}

\author{
Min Jeong Kim (1), Chang Ki Shim*, and Jong-Ho Park \\ Organic Agriculture Division, National Institute of Agricultural Sciences, Wanju 55365, Korea \\ (Received on September 6, 2021; Revised on October 8, 2021; Accepted on October 10, 2021)
}

Although late blight is an important disease in ecofriendly potato cultivation in Korea, it is highly dependent on the use of eco-friendly agricultural materials and the development of biological control technology is low. It is a necessary to develop an effective biocontrol agent to inactivate late blight in the field. AFB2-2 strain is a gram-positive with peritrichous flagella. It can utilize 20 types of carbon sources, like L-arabinose, and Dtrehalose at $35^{\circ} \mathrm{C}$. The optimal growth temperature of the strain is $37^{\circ} \mathrm{C}$. It can survive at $20-50^{\circ} \mathrm{C}$ in tryptic soy broth. The maximum salt concentration tolerated by AFB2-2 strain is $7.5 \% \mathrm{NaCl}$. AFB2-2 strain inhibited the mycelial growth of seven plant pathogens by an average inhibitory zone of $10.2 \mathrm{~mm}$ or more. Among the concentrations of AFB2-2, $10^{7} \mathrm{cfu} / \mathrm{ml}$ showed the highest control value of $85.7 \%$ in the greenhouse. Among the three concentrations of AFB2-2, the disease incidence and severity of potato late blight at $10^{7} \mathrm{cfu} / \mathrm{ml}$ was lowest at 0.07 and 6.7 , respectively. The nucleotide sequences of AFB2-2 strain were searched in the NCBI GenBank; Bacillus siamensis strain KCTC 13613, Bacillus velezensis strain CR-502, and Bacillus amyloliquefaciens strain DSM7 were found to have a genetic similarity of $99.7 \%, 99.7 \%$, and $99.5 \%$, respectively.

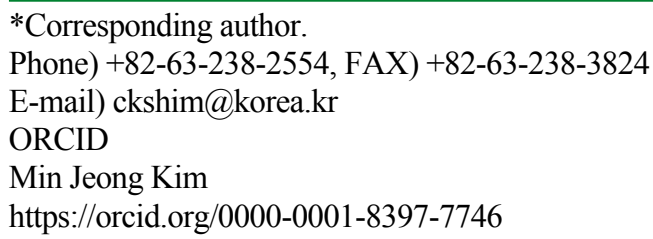

Handling Editor : Mee Kyung Sang

(c) This is an Open Access article distributed under the terms of the Creative Commons Attribution Non-Commercial License (http:// creativecommons.org/licenses/by-nc/4.0) which permits unrestricted noncommercial use, distribution, and reproduction in any medium, provided the original work is properly cited.

Articles can be freely viewed online at www.ppjonline.org.
The AFB2-2 strain was found to harbor the biosynthetic genes for bacillomycin $\mathrm{D}$, iturin, and surfactin. Obtained data recommended that the $B$. velezensis AFB22 strain could be considered as a promising biocontrol agent for $P$. infestans in the field.

Keywords : Bacillus velezensis AFB2-2, biocontrol agents, Phytotphthora infestans, potato

Potato (Solanum tuberosum L.) is one of the most important vegetable crops in Korea and worldwide. However, its susceptibility to plant diseases including late blight caused by Phytophthora infestans makes its cultivation challenging (Chycoski and Punja, 1996; Desjardins et al., 1995; Giddings and Berg, 1919; Hahm et al., 1978; Park et al., 2011).

Late blight is one of the devastating diseases affecting Solanaceous crops like potato and tomato in most potato producing parts of Korea (Hahm et al., 1978; Park et al., 2011; Ryu et al., 2005) and worldwide. The worldwide economic damages of potatoes due to late blight are 5.0 billion dollars annually in 2004 (International Potato Center, 2004; Latijinhouwers et al., 2004). Late blight occurrence is favored by high humidity, dew, wet weather, and moderate temperatures $\left(10-27^{\circ} \mathrm{C}\right)(\mathrm{Choi}, 2007)$. When the environmental conditions are favorable for P. infestans, the disease can spread rapidly and defoliate entire fields within 3 weeks (Kirk et al., 2004). Late blight causes premature potato vine and tuber rots, and thereby results in poor yields. Generally, late blight affects folia parts of both potato and tomato along with potato tubers and tomato fruit (Novy et al., 2006). Potato late blight is easily transmitted by affected potato tubers. Planting non-certified potato seeds saved or obtained from neighbors increases the risk of incidence of late blight in the field.

In Korea, there are a total of 18 pesticides registered 
for the control of potato late blight, however, $20-95 \%$ of late blight strain show resistance to the fungicide, metalaxyl (Kim et al., 2000; Lee et al., 1994; Park et al., 2010; Zhang et al., 2005). In the 1980s, resistant potato late blight strain appeared in European fields, in the Netherlands and Switzerland, followed by the occurrence of metalaxylresistant strains in Ireland and Israel (Cohen and Reuveni, 1983; Dowly and O'sullivan, 1981; Fry et al., 1992). Therefore, eco-friendly environmental products are in high demand in the pesticide market. With the increase in a national income, the interest in health, and consumption of eco-friendly and organic agricultural products is rapidly increasing. Biological control has been recognized as a method that can replace synthetic pesticides in controlling various plant diseases (Chet and Inbar, 1994; Folman et al., 2004; Quimby et al., 2002). Moreover, various antagonistic microorganisms and naturally derived non-toxic substances are being used as biological pesticides.

With the rapid spread of organic farming, various methods for improving soil health are being explored, but there are very few competant organic materials available. Various beneficial microorganisms exist in an environment rich in organic matter, in the soil around the rhizosphere of plants (Yeo et al., 2009). In organic potato cultivation fields, diseases caused by soil transmitted pathogens such as late blight, common scab, and soft rot are frequent and cause severe economic damage. It is, therefore, necessary to develop eco-friendly plant disease control technologies. Late blight is one of the most destructive diseases in organic as well as conventional potato cultivation in Korea. The disease is known to destroy the entire leaves or foliar parts of the plant within 2 weeks of infection in organic fields (Ryu et al., 2005).

In recent years, the interest in biological control of plant pathogens has significantly increased due to the need for the introduction of environmentally friendly alternatives to minimize the intensive use of chemical pesticides (Ongena and Jacques, 2008; Quimby et al., 2002). Besides the antibiotic effect, many microbial strains also show growth-promoting properties on the plants. Among bacteria, the strains from genera Bacillus, Pseudomonas, Streptomyces, and Agrobacterium play an important role in biological control as soil and plant-associated microorganisms (Athukorala et al., 2009; Shim et al., 2015). Biocontrol agents are defined as the products consisting of living microorganisms used to combat plant pathogens. However, until the last decade, biocontrol products constituted only $1 \%$ of the sales of all agricultural chemicals on the global market (Fravel, 2005). For most biocontrol agents, the antagonistic ability selected under limited conditions in the laboratory does not exhibit antagonistic effects in the field as their anchoring power in the rhizosphere is low. However, the use of biological control agents and products is indispensable in organic farming (Lynch et al., 2012).

In many cases, microorganisms such as Trichoderma harzianum (Elad and Kapat, 1999; Wang et al., 2021; Yao et al., 2016), Bacillus subtilis (El-Naggar et al., 2016), and Burkholderia gladioli (Kang et al., 2013) were sufficient to suppress the late blight disease in the field. Bacterial biocontrol agents from the genus Bacillus, primarily Bacillus velezensis, have effectively controlled the common potato disease caused by $R$. solani in several countries for a decade (Asaturova et al., 2021; Dinu et al. 2019; El-Naggar et al., 2016).

This study was conducted with the objective to identify Bacillus sp. AFB2-2 strain with optimal temperature. The study is also an attempt to estimate the antifungal ability of AFB2-2 strain against $P$. infestans and identified by molecular analysis. Moreover, we screened the strain for the presence of cyclic lipopeptide synthesis genes and evaluated its efficacy in controlling potato late blight in greenhouse condition and an organic potato field.

\section{Materials and Methods}

Plant pathogens. Seven plant pathogens potato fusarium wilt (Fusarium oxysporum, KACC 43207); potato gray mold (Botrytis cinerea, KACC 40963), potato black scurf (Rhizoctonia solani, KACC 40130), potato white mold (Sclerotinia sclreotiorum, KACC 41069), hot-pepper damping-off (Pythium ultimum, KACC 40705), potato late blight (Phytophthora infestans, KACC 43073), and hot-pepper anthracnose (Colletotrichum gloeosporioides, KACC 40003) were used in this study, and were kindly provided by the National Agricultural Microorganisms Resource Center (KACC). Seven plant pathogens, except for $P$. infestance, were cultured in PDA ( $20 \mathrm{~g}$ potato, $18 \mathrm{~g}$ dextrose, $18 \mathrm{~g}$ agar, $1,000 \mathrm{ml}$ sterile water) medium, and the late blight fungus was grown on V8-juice agar (150 $\mathrm{ml} \mathrm{V8-juice,} 850 \mathrm{ml}$ distilled water, $3 \mathrm{~g} \mathrm{CaCO}_{3}$, and $18 \mathrm{~g}$ agar). The culture conditions were incubated at $20-25^{\circ} \mathrm{C}$ for 7 days with due consideration of the optimal growth conditions of the pathogens. Actively growing mycelia were selected from the plates and subcultured in freshly prepared V8-juice or PDA media for further incubation at their respective optimal growth temperature.

Isolation and culture of antagonistic bacteria. To select strains with excellent inhibitory effect on potato late blight, soil samples were collected from a depth of $15 \mathrm{~cm}$ centered 
on the rhizosphere of potatoes with excellent growth at an organic potato cultivation farmhouse in Sillim-myeon, Wonju-si, Gangwon-do, in mid-June. To increase the selection frequency of the endospore-forming Bacillus, $1 \mathrm{~g}$ of the treated soil sample and $9 \mathrm{ml}$ of physiological saline $(0.85 \% \mathrm{NaCl})$ were added and treated in a water bath at $80^{\circ} \mathrm{C}$ for $60 \mathrm{~min}$ to lower the density of gram-negative bacteria. The heat-treated soil sample was then diluted to a concentration of $10^{-4}$ to $10^{-6}$ in a glass tube containing $9 \mathrm{ml}$ of sterilized distilled water, spread on the tryptic soy agar (TSA) medium, and incubated at $28^{\circ} \mathrm{C}$ for 2 days. After culturing, a single colony was isolated and purified, suspended in a cryotube $(2.0 \mathrm{ml})$ containing $20 \%$ glycerin and then stored in a $-75^{\circ} \mathrm{C}$ cryofreezer.

In order to test the antifungal activity of 320 bacterial isolates isolated from organic potato cultivation soil, the PDA medium was autoclaved and cooled to $50^{\circ} \mathrm{C}$. Then, pure cultured $P$. infestans mycelium and $F$. oxysporum conidia were added, respectively, and a culture medium was prepared in advance. Antifungal activity of the isolates was primarily selected by inoculating the culture medium containing the plant pathogens by using a sterilized toothpick to inoculate the single colony of the tested isolate.

Identification of Bacillus sp. AFB2-2. The morphological and physiological characterization of the AFB2-2 strain was based on the gram reaction, shape, motility, endospore formation, and growth at different temperatures as well as on the $\mathrm{NaCl}$ concentrations in the in vitro assays.

The cell morphology of the strain was observed under transmission electron microscope (LEO 912AB, ZEISS, Oberkochen, Germany) at $\times 10,000$ magnification using cells grown for 2 days at $28^{\circ} \mathrm{C}$ on the TSA medium and prepared on Formvar-coated grids (Plano, Wetzlar, Germany) followed by staining with 3\% uranyl acetate, as described by Hartmann et al. (2010).

The gram reaction of the strain was determined by nonstaining methods using potassium hydroxide $(\mathrm{KOH})$, as described by Buck (1982) and Halebian et al. (1981).

The isolates were identified with reference to their biochemical profiles of single-carbon source assimilation ability using the API 50CH/B Test Kit (BioMérieux, Marcy l'Etoile, France), following the manufacturer's instructions. The Analytical Profile Index (API) test kit results were interpreted using the API database of the Apiweb software (version 4.0, BioMérieux).

For the thermotolerant screening, the AFB2-2 strain was grown in tryptic soy broth (TSB) medium at $10^{\circ} \mathrm{C}, 20^{\circ} \mathrm{C}$, $25^{\circ} \mathrm{C}, 30^{\circ} \mathrm{C}, 35^{\circ} \mathrm{C}, 37^{\circ} \mathrm{C}, 40^{\circ} \mathrm{C}, 45^{\circ} \mathrm{C}, 48^{\circ} \mathrm{C}, 50^{\circ} \mathrm{C}, 52^{\circ} \mathrm{C}$, $55^{\circ} \mathrm{C}$, and $60^{\circ} \mathrm{C}$ in an RTS-8 Multi-channel Bioreactor
(Biosan Co. Ltd., Riga, Lativia) for $25 \mathrm{~h}$ and the growth was recorded as optical density (OD) with noninvasive real-time cell concentration measurement at $600 \mathrm{~nm}$.

The AFB2-2 strain was tested for its salt tolerance based on the relative changes in their growth as per a previously published protocol (Shim et al., 2015). For evaluation, the salt tolerance ability of the newly isolated strains was performed using a $100 \mu \mathrm{l}$ aliquot of a preinoculum to inoculate $50 \mathrm{ml}$ of TSB medium supplemented with different concentrations $(0 \%, 1 \%, 2 \%, 2.5 \%, 3.0 \%, 5.5 \%, 6.0 \%$, and $7.5 \%$ ) of $\mathrm{NaCl}$. After inoculation, the bacterial growth was evaluated using the RTS-8 Multi-channel Bioreactor (Biosan Co. Ltd.) at $37^{\circ} \mathrm{C}$ for $25 \mathrm{~h}$. The absorbance of the culture was evaluated automatically at the 30-min interval at $600 \mathrm{~nm}$ in the RTS-8 Multi-channel Bioreactor. The highest $\mathrm{OD}$ value obtained at different $\mathrm{NaCl}$ concentrations was considered as the maximum salinity tolerance capacity.

In vitro inhibition assay for $P$. infestans on solid media. The candidate isolates AFB2-2 were screened for their antagonistic ability against seven plant pathogens, including $P$. infestans, in vitro by using the dual culture technique using the method described by Estrella et al. (2001) and Kerkeni et al. (2007). Therefore, the AFB2-2 isolate was cultured by streaking at $2 \mathrm{~cm}$ from the edge of a $9 \mathrm{~cm}$ diameter Petri dish containing the PDA medium. An 8-mm mycelial agar disk was uniformly cut from the leading edge of a 5-dayold culture of seven plant pathogens with an $8 \mathrm{~mm}$ diameter corker borer and deposited in an opposed position 2 $\mathrm{cm}$ away from the other set of the plate. For the untreated plates, an $8 \mathrm{~mm}$ mycelial agar disk of the pathogens only was placed at $2 \mathrm{~cm}$ from the edge of a $9 \mathrm{~cm}$ diameter Petri dish containing only fresh PDA medium.

Three plates were used as replicates for each treatment as well as for the control. Inoculated plates were incubated at $25 \pm 1{ }^{\circ} \mathrm{C}$ until the fungal growth of the control plates reached the edge of the Petri dishes. The reduction in the mycelial growth of the seven plant pathogens was calculated using the formula suggested by Hwang et al. (2006) and Shim et al. (2015), as follows:

$$
\mathrm{MI}=\mathrm{RC}-\mathrm{RT} / \mathrm{RC} \times 100
$$

, where MI = mycelial growth inhibition (\%) of the pathogen, $\mathrm{RC}=$ radial growth of the pathogen in the control plates $(\mathrm{cm})$, and $\mathrm{RT}=$ radial growth of the pathogen treated with antagonistic bacteria AFB2-2 in a dual culture plate (cm).

Identification based on 16S rRNA gene sequencing and phylogenetic analyses. The pure isolated AFB2-2 colony 
was inoculated in a $9 \mathrm{ml} \mathrm{TSB}$ medium and cultured for 24 $\mathrm{h}$ with continuous stirring at $28^{\circ} \mathrm{C}$, after which the genomic DNA was extracted by using the modified bead beater phenol method. For molecular identification, the selected AFB2-2 strain was subjected to 16S rRNA gene sequence analyses. The AFB2-2 strain was grown in TSB and the genomic DNA was extracted (Saitou and Nei, 1987; Sambrook et al., 1989). The 16S rRNA gene was amplified by PCR using the forward primer 27F 5'-AGAGTTTGATCCTGGCTCAG-3' and the reverse primer 1492R 5'-GGTTACCTTGTTACGACTT-3'. The amplification of $16 \mathrm{~S}$ rRNA gene sequences was performed using the Thermal Cycler (Applied Biosystems TC1, Pittsburgh, PA, USA) with a $25 \mu \mathrm{l}$ reaction volume. Each reaction mixture contained a $2 \mu \mathrm{l} 10 \times$ buffer with magnesium chloride $\left(\mathrm{MgCl}_{2}\right), 0.5 \mu \mathrm{l}$ of $10 \mathrm{mM}$ dNTPs, $2 \mu \mathrm{l}$ of 10 pmol-PCR primers, 2 units of Taq DNA polymerase (TaKaRa HotTaq, Tokyo, Japan), and $2 \mu \mathrm{l}$ of DNA template (50-100 $\mathrm{ng}$ ), and the volume was increased to $25 \mu \mathrm{l}$ with double distilled sterile water. PCR was performed for the internal transcribed spacer (ITS) region using the following steps: (1) $94^{\circ} \mathrm{C}$ for $5 \mathrm{~min}$; (2) 30 cycles of $92^{\circ} \mathrm{C}$ for $60 \mathrm{~s}, 58^{\circ} \mathrm{C}$ for $60 \mathrm{~s}$, and $72^{\circ} \mathrm{C}$ for $90 \mathrm{~s}$; and (3) a final extension step at $72^{\circ} \mathrm{C}$ for $5 \mathrm{~min}$. For the ITS DNA fragment sequencing, template DNA $(20 \mu \mathrm{l})$ was directly prepared from the PCR products by purification using a column-based purification kit (Qiagen, Hilden, Germany). Sequencing was then performed with Chunlab Co. (Seoul, Korea). The obtained 16S rRNA gene sequences were compared with sequences previously deposited in the National Center for Biotechnology database (NCBI, https://blast.ncbi.nlm.hih.gov/Blast. cgi). A molecular phylogenetic tree based on the amino acid sequence of the 16S rRNA gene of the AFB2-2 strain was performed automatically using the MEGA version 7 (Kumar et al., 2016) after multiple alignments of the data with the CLUSTAL W (Thompson et al., 1994). Distances were obtained using options according to the Kimura twoparameter model (Kim et al., 2016; Kimura, 1980), and clustering was performed using the Neighbor-Join algorithms (Saitou and Nei, 1987) to a pairwise matrix, which was inferred by using the maximum composite likelihood method, with a 1,000-replicate (Felsenstein, 1985) bootstrap test using MEGA 7. The phylogenetic tree was drawn to scale, with the branch lengths measured by the number of substitutions per site.

Screening of secondary metabolite biosynthesis genes of AFB2-2 strain. PCR was performed with specific primers to detect bacillomycin $\mathrm{D}(b m y \mathrm{~A})$, fengycin (fen $\mathrm{D})$, iturin A (ituA), surfactin (srfA), and zwittermicin A (zwiA) synthesis-related genes exhibiting antagonistic activity against Bacillus sp. strains (Table 1). For the PCR reaction, a reaction mixture (AccuPower HotStart PCR PreMix, Bioneer Co., Daejeon, Korea) was used to which $1 \mu$ l of genomic DNA (50 ng) and 10 pmol of each primer were mixed, with $20 \mu \mathrm{l}$ set as the final volume. For the PCR reaction, the initial denaturation reaction (initial denaturation; $95^{\circ} \mathrm{C}$, $3 \mathrm{~min}$ ), amplification reaction (denaturation: $95^{\circ} \mathrm{C}$ for 30 s, binding: $55^{\circ} \mathrm{C}$ for $45 \mathrm{~s}$, and elongation: $72^{\circ} \mathrm{C}$ for $1 \mathrm{~min}$ ) was repeated 30 times, and the final elongation reaction was performed at $72^{\circ} \mathrm{C}$ for $10 \mathrm{~min}$. The presence and size of the amplified PCR product were confirmed via electrophoresis on $1.2 \%$ agarose gel in $0.8 \%$ TSB buffer.

Control efficacy of AFB2-2 strain against potato late blight in the pot and field trials. Mycelium fragments of potato late blight ( $P$. infestans) were placed on the V8-juice agar medium and cultured for 7 days in a low-temperature incubator under dark at $25^{\circ} \mathrm{C}$. When the aerial mycelium on the surface was removed and placed under fluorescent light for 1 day, sporangia were formed. The sporangia were then harvested from the medium to form zoospores from

Table 1. PCR primer for the detection of biosynthesis genes of the Bacillus sp. AFB2-2 strain

\begin{tabular}{|c|c|c|c|c|}
\hline Antibiotic & Gene & Primers & Sequence $\left(5^{\prime}-3^{\prime}\right)$ & Reference \\
\hline \multirow[t]{2}{*}{ Bacillomycin D } & bmyA & BACC1F & GAAGGACACGGCAGAGAGTC & Athukorala et al. (2009) \\
\hline & & BACC1R & CGCTGATGACTGTTCATGCT & \\
\hline \multirow[t]{2}{*}{ Fengycin } & fenD & FEND1F & TTTGGCAGCAGGAGAAGTTT & \\
\hline & & FEND1R & GCTGTCCGTTCTGCTTTTTC & \\
\hline \multirow[t]{2}{*}{ Iturin A } & ituA & ITUD1F & GATGCGATCTCCTTGGATGT & \\
\hline & & ITUD1R & ATCGTCATGTGCTGCTTGAG & \\
\hline \multirow[t]{2}{*}{ Surfactin } & $\operatorname{srfA}$ & SUR3F & ACAGTATGGAGGCATGGTC & \\
\hline & & SUR3R & TTCCGCCACTTTTTCAGTTT & \\
\hline \multirow[t]{2}{*}{ Zwittermicin A } & zwiA & ZWITF2 & TTGGGAGAATATACAGCTCT & \\
\hline & & ZWITR1 & GACCTTTTGAAATGGGCGTA & \\
\hline
\end{tabular}


sporangia, which were left in the refrigerator at $4^{\circ} \mathrm{C}$ for 2 $\mathrm{h}$. The least population density of zoospore was more than $10^{6-7}$ cells/ml that was drenched in the soil and spray on the 40-day-old Sumi potato plant at $2 \mathrm{~h}$ after treatment of 100 times diluted antifungal bacterial culture solution of AFB 2-2 in distilled water. $100 \mathrm{ml}$ of each treatment was irrigated in the root and sprayed on the stems and leaves of potato plant. And the control treatment treated with spray of the 100 times diluted TSB media in distilled water. All experiments were conducted at least twice, a set of five replicates with 10 plants was performed per treatment. The number of infested plant was recorded every 7 days for 28
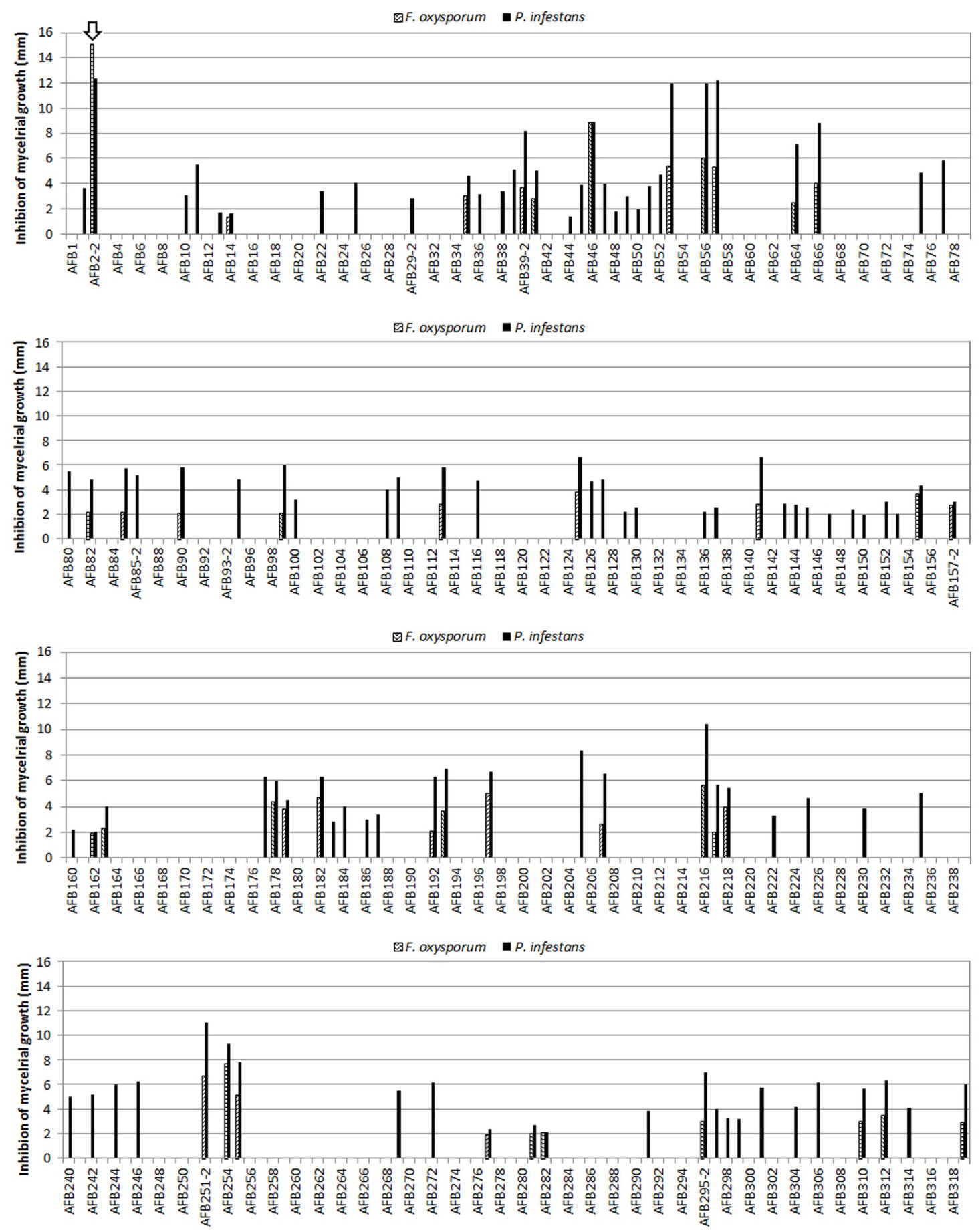

Fig. 1. Screening of antifungal activity of 320 bacterial strains against Phytophthora infestans and Fusarium oxysporum on medium. 
days after treatment.

To investigate the control effect of the AFB2-2 strain on potato late blight in organic potato cultivation fields in 2019. The potato of the Sumi cultivar was sown in a farmhouse field in Sillim-myeon, Wonju-si, Gangwon-do, on May 15, and then grown using the organic cultivation method. Field trials were performed according to Lamsal et al. (2013). A total of four treatments included control was set up for the experiment, with randomized complete blocks. In the farm field, 30 healthy potato seeds were sown at intervals of $30 \times 70 \mathrm{~cm}$ in $6.6 \mathrm{~m}^{2}$, and the experiments was conducted with four repetitions of the completely randomized design for a total of 16 plots. A total of three investigations were conducted. From June 26, the beginning of the onset, the AFB2-2 culture solution was sprayed four times with 14-day intervals to sufficiently wet the aboveground portions, and then the late blight disease severity (\%) was recorded up to 90 days of planting by the scale from 0 to 4 according to Cohen et al. (1991) based on the infected leaf area as follows: 0 , no infested leaves; 1 , $0.1-25 \%$ infested leaves area; $2,25.1-50 \%$ infested leaves area; $3,50.1-75 \%$ infested leaves area; 4 , more than $75.1 \%$ infested leaves area.

Percentage of infected plant (\%) was recorded up to 90 days of planting and based on the infected leaf area as follows:

Percentage of Infected Plant $(\%)=($ Number of Infected plant/Number tested plant $) \times 100$

Weather conditions. The meteorological parameters (soil and atomospheric temperature) were recorded by using a portable weather station WatchDog 1000 Series Micro Stations (Spectrum Technologies Instruments, Aurora, IL, USA) at $1.2 \mathrm{~m}$ height inside the study field. The soil temperature was detected by SMEC 300 soil moisture/EC/ Temperature senor (Spectrum Technologies Instruments) placed in $10 \mathrm{~cm}$ depth of soil under black PVC film. The records were extracted per hour.

Statistical analysis. The step of gathering the experimental data was repeated at least thrice. All the data were subjected to statistical analysis using the SAS (version 9.2_PC32, SAS Institute Inc., Cary, NC, USA). Significance testing between treatments was analyzed using Duncan's multiple range tests at a $5 \%$ level.

\section{Results}

Evaluation of biological properties of AFB2-2 strain. Among a total of 320 isolates from organic potato cultiva-
Table 2. Morphological characteristics and the estimation of carbon sources (carbohydrates) of Bacillus sp. AFB2-2

\begin{tabular}{|c|c|c|}
\hline \multirow{2}{*}{ Carbohydrates } & \multicolumn{2}{|c|}{ Incubation temperature $\left({ }^{\circ} \mathrm{C}\right)$} \\
\hline & 28 & 35 \\
\hline Control & - & - \\
\hline Glycerol & +++ & +++ \\
\hline Erythritol & - & - \\
\hline D-Arabinose & - & - \\
\hline L-Arabinose & - & + \\
\hline D-Ribose & - & + \\
\hline D-Xylose & - & - \\
\hline L-Xylose & - & - \\
\hline D-Adonitol & - & - \\
\hline Methyl- $\beta$-D-xylopyranoisde & - & - \\
\hline D-Galactose & - & - \\
\hline D-Glucose & ++ & ++ \\
\hline D-Fructose & + & + \\
\hline D-Mannose & ++ & ++ \\
\hline L-Sorbose & - & - \\
\hline L-Rhamnose & - & - \\
\hline Dulcitol & - & - \\
\hline Inositol & - & +++ \\
\hline D-Mannitol & ++ & ++ \\
\hline D-Sorbitol & +++ & +++ \\
\hline Methyl- $\alpha$-D-mannopyranoside & - & - \\
\hline Methyl- $\alpha$-D-glucopyranoside & - & + \\
\hline N-Acetylglucosamine & - & - \\
\hline Amygdalin & - & + \\
\hline Arbutin & - & + \\
\hline Esculin ferric citrate & ++++ & ++++ \\
\hline Salicin & - & + \\
\hline D-Cellobose & + & ++ \\
\hline D-Maltose & - & +++ \\
\hline D-Lactose & - & + \\
\hline D-Melibiose & - & - \\
\hline S-Saccharose (sucrose) & + & + \\
\hline D-Trehalose & ++ & +++ \\
\hline Inulin & - & - \\
\hline D-Melezitose & - & - \\
\hline D-Raffinose & - & + \\
\hline Amidon (starch) & - & + \\
\hline Glycogen & - & + \\
\hline Xylitol & - & - \\
\hline Gentiobiose & + & + \\
\hline D-Turanose & - & - \\
\hline D-Lyxose & - & - \\
\hline D-Tagatose & - & - \\
\hline D-Fucose & - & - \\
\hline L-Fucose & - & - \\
\hline D-Arabitol & - & - \\
\hline L-Arabitol & - & - \\
\hline Potassium gluconate & - & - \\
\hline Potassium 2-ketogluconate & - & - \\
\hline Potassium 5-ketogluconate & - & - \\
\hline
\end{tabular}

Morphological shape: white, rods; Gram stain: +, Spore: +; Mortality: +; Flagella: Positive (Peritrichous); Cell size $(\mu \mathrm{m}):(1.56 \pm 0.13)$ $\times(0.58 \pm 0.05)$. 


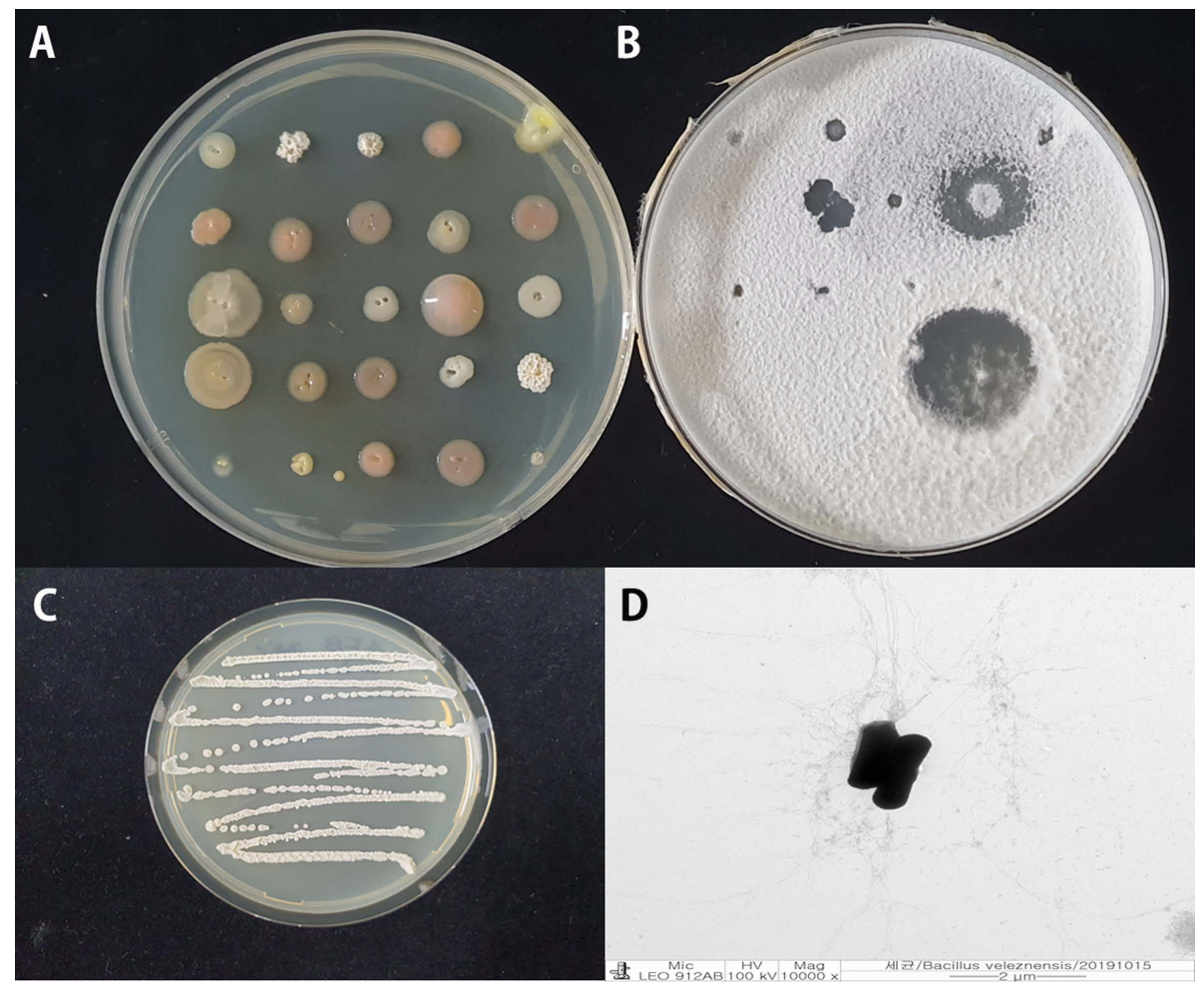

Fig. 2. Culture on tryptic soy agar medium (A-C) and electron microscopic observation (D) of Bacillus sp. AFB2-2 by transmission electron microscopy $(\times 10,000,100 \mathrm{Kv})$. Scale bar $=2 \mu \mathrm{m}$.

tion soil, the AFB2-2 strain, showing the highest mycelial inhibition in $P$. infestans, was identified (Fig. 1). AFB2-2 strain is a gram-positive spore-forming motile bacterium with peritrichous flagella. Observation under the transmission electron microscope revealed that its cell size was (1.56 $\pm 0.13) \times(0.58 \pm 0.05) \mu \mathrm{m}$ (Table 2, Fig. 2).

Evaluation of carbon utilization ability of AFB2-2 strain. The utilization of 49 carbon sources by AFB2-2 strain was tested using API $50 \mathrm{CH}$ Kit at two incubation temperatures $28^{\circ} \mathrm{C}$ and $35^{\circ} \mathrm{C}$. At $28^{\circ} \mathrm{C}$, the AFB2-2 strain was able to utilize 11 carbon sources glycerol, D-glucose, D-fructose, D-mannose, D-mannitol, D-morbitol, esculin ferric citrate, D-cellobiose, S-saccharose, D-trehalose, and gentiobiose (Table 3). At $35^{\circ} \mathrm{C}$, AFB2-2 strain utilized 20 kinds of carbon sources, glycerol, L-arabinose, D-ribose, D-glucose, D-fructose, D-mannose, inositol, D-mannitol, D-sorbitol, esculin ferric citrate, salicin, D-cellobiose, Dmaltose, D-lactose, S-saccharose, D-trehalose, D-raffinose, amidon (starch), glycogen, and gentiobiose (Table 2). At $35^{\circ} \mathrm{C}$, which is the near-optimal temperature for the growth of bacterial cultures, the AFB2-2 strain was found to utilize

Table 3. Comparison of phenotype among AFB2-2 strain and type strains of Bacillus sp. in silico

\begin{tabular}{|c|c|c|c|c|c|}
\hline \multirow{2}{*}{ Assimitation } & \multirow{2}{*}{$\frac{\text { In this study }}{\text { AFB2-2 }}$} & \multicolumn{4}{|c|}{ Jin et al. (2018) } \\
\hline & & $\mathrm{DSM}^{\mathrm{a}}$ & KCTC $13613^{b}$ & LMG $22478^{c}$ & MWS28 \\
\hline L-Arabinose & + & $\mathrm{W}$ & + & + & + \\
\hline D-Xylose & - & W & + & + & + \\
\hline D-Mannose & ++ & + & W & + & + \\
\hline D-Trehalose & +++ & - & - & + & + \\
\hline
\end{tabular}

W, weak growth; +, growth; ++, well growth; +++, very well growth; -, no growth.

${ }^{a}$ DSM7: Bacillus amyloliquefaciens.

${ }^{\mathrm{b}} \mathrm{KCTC}$ 13613: Bacillus siamensis.

${ }^{\circ}$ LMG 22478: Bacillus velezensis.

${ }^{\mathrm{d}}$ MWS28: Bacillus velezensis. 
Table 4. Salt tolerance of Bacillus sp. AFB2-2 estimated at different $\mathrm{NaCl}$ concentrations

\begin{tabular}{ccccccc}
\hline \multirow{2}{*}{$\begin{array}{l}\mathrm{NaCl} \text { contents } \\
(\mathrm{w} / \mathrm{v}, \%)\end{array}$} & \multicolumn{5}{c}{ Optical density $(\mathrm{OD}, 600 \mathrm{~nm})$} \\
\cline { 2 - 7 } & $0 \mathrm{~h}$ & $5 \mathrm{~h}$ & $10 \mathrm{~h}$ & $15 \mathrm{~h}$ & $20 \mathrm{~h}$ & $25 \mathrm{~h}$ \\
\hline 0 & $0 \pm 0$ & $1.35 \pm 0.02$ & $1.58 \pm 0.01$ & $1.78 \pm 0.02$ & $2.23 \pm 0.01$ & $2.55 \pm 0.02$ \\
1.0 & $0 \pm 0$ & $1.35 \pm 0.01$ & $1.58 \pm 0.02$ & $1.79 \pm 0.01$ & $2.24 \pm 0.01$ & $2.58 \pm 0.02$ \\
2.0 & $0 \pm 0$ & $1.36 \pm 0.02$ & $1.57 \pm 0.01$ & $1.79 \pm 0.01$ & $2.25 \pm 0.02$ & $2.57 \pm 0.01$ \\
2.5 & $0 \pm 0$ & $1.41 \pm 0.03$ & $1.6 \pm 0.02$ & $1.91 \pm 0.01$ & $2.31 \pm 0.02$ & $2.64 \pm 0.02$ \\
3.0 & $0 \pm 0$ & $1.20 \pm 0.02$ & $1.37 \pm 0.03$ & $1.65 \pm 0.02$ & $2.12 \pm 0.02$ & $2.34 \pm 0.01$ \\
5.5 & $0 \pm 0$ & $1.12 \pm 0.01$ & $1.30 \pm 0.02$ & $1.38 \pm 0.01$ & $1.56 \pm 0.01$ & $1.85 \pm 0.01$ \\
6.0 & $0 \pm 0$ & $0.90 \pm 0.01$ & $1.10 \pm 0.01$ & $1.25 \pm 0.02$ & $1.43 \pm 0.01$ & $1.65 \pm 0.02$ \\
7.5 & $0 \pm 0$ & $0.90 \pm 0.01$ & $1.10 \pm 0.01$ & $1.2 \pm 0.01$ & $1.41 \pm 0.01$ & $1.50 \pm 0.01$ \\
\hline
\end{tabular}

nine more carbon sources than that at $28^{\circ} \mathrm{C}$ (Table 2).

In Table 3, the biochemical test results of API50CHB of the AFB2-2 strain were compared with the previously reported biochemical test results of the Bacillus group, showing a higher similarity with the $B$. velezensis group in the use of L-arabinose, D-mannose, and D-trehalose.

Evaluation of temperature and $\mathrm{NaCl}$ tolerance ranges for AFB2-2 strain. AFB2-2 strain was evaluated for their ability to grow at a wide range of temperature conditions $\left(10-60^{\circ} \mathrm{C}\right)$ in the TSB medium. The strain showed normal growth in the range of $20-50^{\circ} \mathrm{C}$; however, higher temperatures $\left(52-60^{\circ} \mathrm{C}\right)$ hampered its growth. It showed optimum growth at $37^{\circ} \mathrm{C}$ with an $\mathrm{OD}_{600}$ of 5.5 at $25 \mathrm{~h}$ after inoculation in the TSB medium (Fig. 3).

A step-by-step estimation of $\mathrm{NaCl}$ tolerance revealed that the AFB2-2 strain could tolerate up to $7.5 \%$ of $\mathrm{NaCl}$. The AFB2-2 strain was cultured at different salt concentrations, like $0 \%, 1 \%, 2 \%, 2.5 \%, 3 \%, 5.5 \%, 6 \%$, and $7.5 \%$ of $\mathrm{NaCl}$, in the TSB medium to study its salt requirement (Table 4). In the TSB liquid medium, $7.5 \% \mathrm{NaCl}$ is a critical point for the growth of the AFB2-2 strain. AFB2-2 strain showed optimal growth at $2.5 \% \mathrm{NaCl}$, with OD 600 of 2.64 at $25 \mathrm{~h}$ after inoculation (Table 4).

Estimation of antifungal activity test of AFB2-2 strain against plant pathogens. The growth inhibitory effect of AFB2-2 strain was tested on the mycelia of seven major plant pathogens, $F$. oxysporum, $B$. cinerea, $R$. solani, $S$. sclreotiorum, $P$. ultimum, $P$. infestans, and $C$. gloeosporioiedes. AFB2-2 strain inhibited the mycelial growth of seven of these plant pathogens with an average zone of $10.2 \mathrm{~mm}$ or more, 7 days after inoculation (Table 5). Among the seven plant pathogens, $P$. infestans, and $C$. gloeosporioiedes showed the highest mycelial growth inhibition compared with the untreated control at $73.0 \%$ and $71.2 \%$, respectively. In particular, the mycelial growth inhibition by $12.4 \mathrm{~mm}$ was observed against $P$. infestans (Table 5). The AFB2-2 strain showed a mycelial growth inhibitory effect of $40.3 \%$ or more compared with the untreated plant pathogens cultures (Table 5).

Control efficacy of AFB2-2 strain against potato late blight in greenhouse conditions. The efficacy of the AFB2-2 strain in controlling the potato late blight caused by $P$. infestans was assessed in the greenhouse. A 5-dayold culture solution of the AFB2-2 strain was diluted to $10^{5}, 10^{6}$, and $10^{7} \mathrm{cfu} / \mathrm{ml}$ and sprayed on 50 -day old potato plants followed by the treatment with $P$. infestans zoospore suspension $\left(10^{6-7}\right.$ cells $\left./ \mathrm{ml}\right)$. The plants were examined after every 7 days after spray inoculation till the 28th day. The disease incidence of potato late blight in untreated potatoes

Table 5. Evaluation of the antifungal ability of Bacillus sp. AFB2-2 strain against seven major plant pathogens

\begin{tabular}{lccccccc}
\hline \multirow{2}{*}{ Treatment } & \multicolumn{7}{c}{ Mycelia growth of fungal plant pathogens (mm) } \\
\cline { 2 - 7 } & FO & BC & RS & SS & PU & PI & CG \\
\hline AFB 2-2 & $15.1 \pm 1.4$ & $18.1 \pm 1.2$ & $27.1 \pm 1.6$ & $25.3 \pm 1.5$ & $20.3 \pm 1.2$ & $12.4 \pm 1.0$ & $10.2 \pm 1.0$ \\
CK & $41.5 \pm 1.6$ & $45.0 \pm 2.1$ & $45.4 \pm 2.5$ & $45.2 \pm 2.2$ & $45.5 \pm 1.4$ & $46.0 \pm 1.4$ & $35.5 \pm 1.1$ \\
Inhibition (\%) & $63.6 \pm 2.0$ & $59.8 \pm 1.8$ & $40.3 \pm 2.4$ & $44.0 \pm 2.0$ & $55.4 \pm 1.8$ & $73.0 \pm 2.2$ & $71.2 \pm 2.5$ \\
\hline
\end{tabular}

FO, Fusarium oxysporum (KACC 43207); BC, Botrytis cinerea (KACC 40963); RS, Rhizoctonia solani AG2-2 (KACC 40130); SS, Sclerotinia sclreotiorum (KACC 41069); PU, Pythium ultimum (KACC 40705); PI, Phytophthora infestans (KACC 43073); CG, Collectotrichum gloeosporioiedes (KACC 40003). 


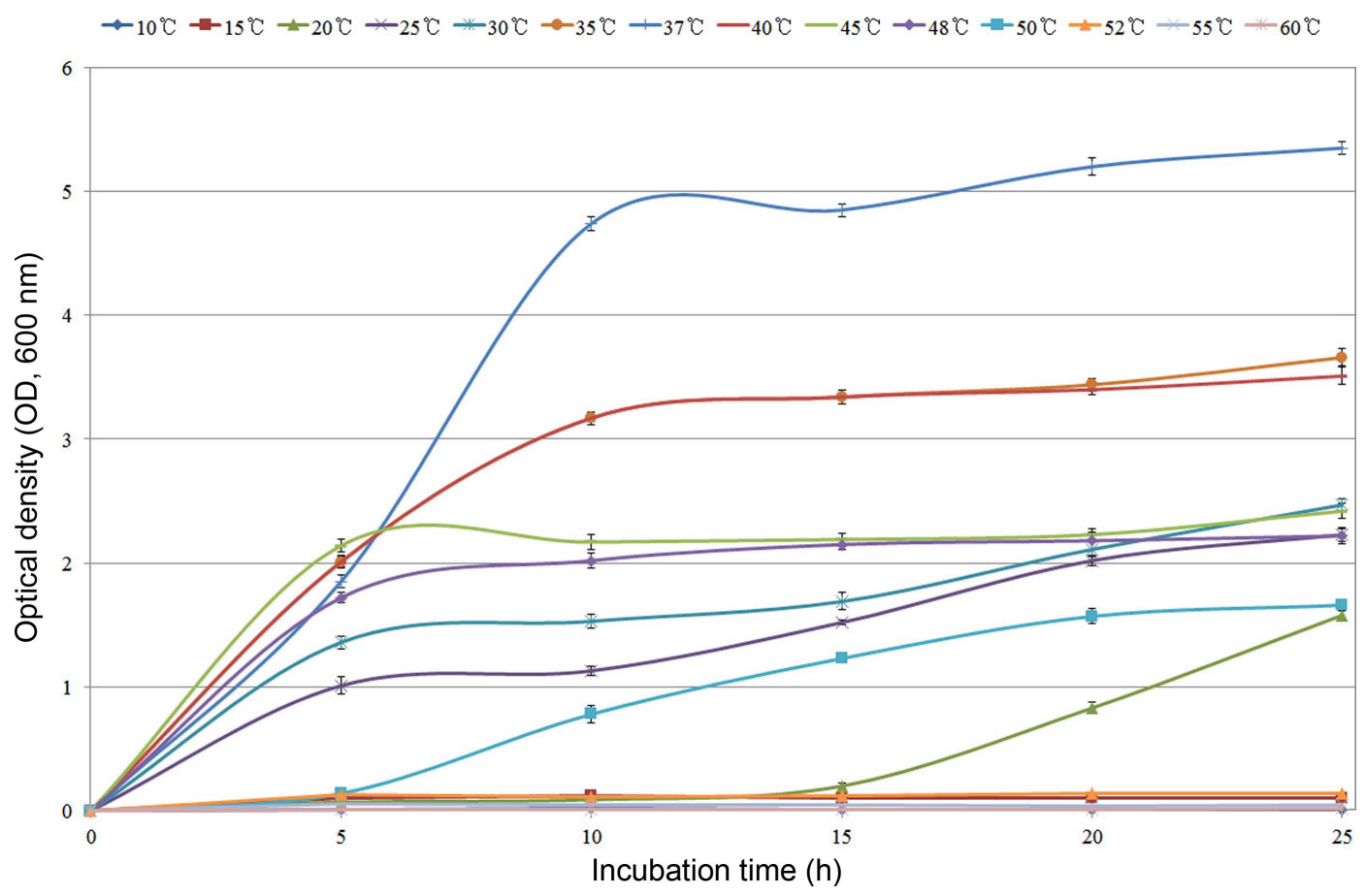

Fig. 3. Effect of the temperature range $\left(10-60^{\circ} \mathrm{C}\right)$ on the growth of Bacillus sp. AFB2-2 in tryptic soy broth medium. Scale bars represent standard errors.

was $46.7 \%$ at 7 days after inoculation and $93.3 \%$ on the 28th day (Table 6). At 7 days after the spray treatment, the AFB2-2 treatment showed a difference in disease incidence with an average of $17.9 \%$ or less. Among the three concentrations of AFB2-2 treatment, the $10^{7} \mathrm{cfu} / \mathrm{ml}$ treatments exhibited a low rate of disease incidence at $2.2 \%$ and a high control value at $95.2 \%$ (Table 6). After 28 days of treatment, disease occurrence was up to $93.3 \%$ in untreated potatoes but $33.3 \%$ or less on average in AFB2-2 treated potatoes. The occurrence of potato late blight was suppressed by AFB2-2 treatment from 7 days to 28 days after treatment. Among the three AFB2-2 treatment concentra- tions, the control value of $10^{7} \mathrm{cfu} / \mathrm{ml}$ of AFB2-2 treatment was the highest at $85.7 \%$ (Table 6).

Control efficacy of AFB2-2 strain against potato late blight in the farm field. To further test the effectiveness of the AFB2-2 strain, naturally occurring potato late blight caused by $P$. infestans was subjected to ABF2-2 treatment. A typical field outbreak of potato blight in Sillimmyeon, Gangwon-do in 2019 was used for this evaluation. Thus, when the incidence rate was $2 \%$ or more on average, ABF2-2 culture solution diluted to $10^{5}, 10^{6}$, and $10^{7} \mathrm{cfu} / \mathrm{ml}$ was sprayed. The inhibitory effect was investigated till the

Table 6. Effect of Bacillus velezensis AFB2-2 on the control of potato late blight caused by Phytophthora infestans under greenhouse conditions

\begin{tabular}{lrccccc}
\hline \multirow{2}{*}{$\begin{array}{l}\text { Treatment content } \\
(\times \mathrm{cfu} / \mathrm{ml})\end{array}$} & \multicolumn{3}{c}{ Disease incidence $(\%)$} & \multicolumn{3}{c}{ Control efficacy $^{\mathrm{b}}(\%)$} \\
\cline { 2 - 6 } & $17.9 \pm 0.47$ & $28.9 \pm 0.94$ & $33.3 \pm 0.82$ & $61.9 \mathrm{c}^{\mathrm{c}}$ & $65.8 \mathrm{c}$ & $64.3 \mathrm{c}$ \\
AFB2-2 $\left(10^{5}\right)$ & $13.3 \pm 0.82$ & $17.8 \pm 0.47$ & $22.2 \pm 0.47$ & $71.4 \mathrm{~b}$ & $78.9 \mathrm{~b}$ & $76.2 \mathrm{~b}$ \\
AFB2-2 $\left(10^{6}\right)$ & $2.2 \pm 0.47$ & $11.1 \pm 0.94$ & $13.3 \pm 0.82$ & $95.2 \mathrm{a}$ & $86.8 \mathrm{a}$ & $85.7 \mathrm{a}$ \\
AFB2-2 $\left(10^{7}\right)$ & $46.7 \pm 0.82$ & $84.4 \pm 0.47$ & $93.3 \pm 0.82$ & - & - \\
Control & & &
\end{tabular}

DAT, days after treatment.

${ }^{a}$ Disease incidence $(\%)=($ Number of Infected plant/Number tested plant $) \times 100$.

${ }^{\mathrm{b}}$ Control value $(\%)=($ Infection percentage of control - Infection percentage of each treatment/Infection percentage of control $) \times 100$.

'Mean separation within columns using Duncan's multiple range test and different letters indicate significant difference $(P \leq 0.05)$. 
Table 7. Control efficacy of the Bacillus velezensis AFB2-2 against potato late blight caused by Phytophthora infestans in organic potato cultivation field

\begin{tabular}{|c|c|c|c|c|c|c|c|c|c|}
\hline \multirow{2}{*}{$\begin{array}{l}\text { Treatment content } \\
(\times \mathrm{cfu} / \mathrm{ml})\end{array}$} & \multicolumn{3}{|c|}{ Disease severity ${ }^{\mathrm{a}}(\%)$} & \multicolumn{3}{|c|}{ Disease incidence $(\%)$} & \multicolumn{3}{|c|}{ Control value $(\%)$} \\
\hline & $7 \mathrm{DAT}$ & $21 \mathrm{DAT}$ & $42 \mathrm{DAT}$ & 7 DAT & $21 \mathrm{DAT}$ & $42 \mathrm{DAT}$ & $7 \mathrm{DAT}$ & $21 \mathrm{DAT}$ & $42 \mathrm{DAT}$ \\
\hline AFB2-2 $\left(10^{5}\right)$ & $0.64 \pm 0.03$ & $0.36 \pm 0.03$ & $0.64 \pm 0.03$ & $26.7 \pm 5.4$ & $33.3 \pm 0.0$ & $31.1 \pm 3.1$ & 42.9 & 48.3 & 60.0 \\
\hline $\operatorname{AFB} 2-2\left(10^{6}\right)$ & $0.46 \pm 0.06$ & $0.24 \pm 0.08$ & $0.46 \pm 0.06$ & $20.0 \pm 5.4$ & $26.7 \pm 5.4$ & $22.2 \pm 3.1$ & 57.1 & 58.6 & 71.4 \\
\hline AFB2-2 $\left(10^{7}\right)$ & $0.22 \pm 0.03$ & $0.18 \pm 0.03$ & $0.22 \pm 0.03$ & $4.4 \pm 3.1$ & $13.3 \pm 0.0$ & $13.3 \pm 5.4$ & 90.5 & 79.3 & 82.9 \\
\hline Control & $2.18 \pm 0.03$ & $1.09 \pm 0.08$ & $2.18 \pm 0.03$ & $46.7 \pm 5.4$ & $64.4 \pm 3.1$ & $77.8 \pm 3.1$ & - & - & - \\
\hline
\end{tabular}

DAT, days after treatment.

${ }^{a}$ Disease severity: 0, no infested leaves; $1,0.1-25 \%$ infested leaves area; 2, 25.1-50\% infested leaves area; 3, 50.1-75\% infested leaves area; 4, $>75.1 \%$ infested leaves area.

${ }^{\mathrm{b}}$ Disease incidence $(\%)=($ Number of Infected plant/Number tested plant $) \times 100$.

${ }^{\mathrm{c}}$ Control value $(\%)=($ Infection percentage of control - Infection percentage of each treatment/Infection percentage of control $) \times 100$.

42nd day at 7 day intervals.

In the case of untreated control, after 7 days of treatment, the potato late blight incidence rate was $24.2 \%$. It increased over time to $42.3 \%$ on the 42 nd day, when the disease severity was 0.76 (Table 7). The disease incidence rate of potato late blight in AFB2-2 treated potatoes differed depending on the treatment concentrations, but the average was $8.9 \%$ or less (Table 7). The occurrence of disease in untreated potatoes was high (42.2\%) 42 days after AFB22 treatment, but in the case of AFB2-2 treated potatoes, it occurred at an average of $13.3 \%$ or less. Among the three concentrations of AFB2-2 treatment, the disease incidence and severity in the $10^{7} \mathrm{cfu} / \mathrm{ml}$ treatment was lowest at 0.07 and 6.7, respectively, whereas the control value against on the 42 nd day was the highest at $84.2 \%$ (Table 7 ).
Monitoring of air and soil temperature in the field. During the test period, the air and soil temperature of organic potato cultivation field were continuously monitored at Wonju from April 10 to May 14, 2020. The daily (24 h) maximum air and soil temperatures are nominally recorded at from 10 am to $2 \mathrm{pm}$. Air temperatures during the cultivation of organic potato were between 8.7 and $29.5^{\circ} \mathrm{C}$ for all experiments. And, soil temperatures of the field were 9.9 to $32.7^{\circ} \mathrm{C}$ (Fig. 4). Between April 30 and May 8, the air and soil temperature of the potato field was maintained above $25^{\circ} \mathrm{C}$. Moreover, during the test period, except for April 25 , most of the soil temperature was higher than the atmospheric temperature by $0.4^{\circ} \mathrm{C}$ or more (Fig. 4).

Identification of AFB2-2 strain based on biological and molecular characteristics. The isolated strain AFB2-

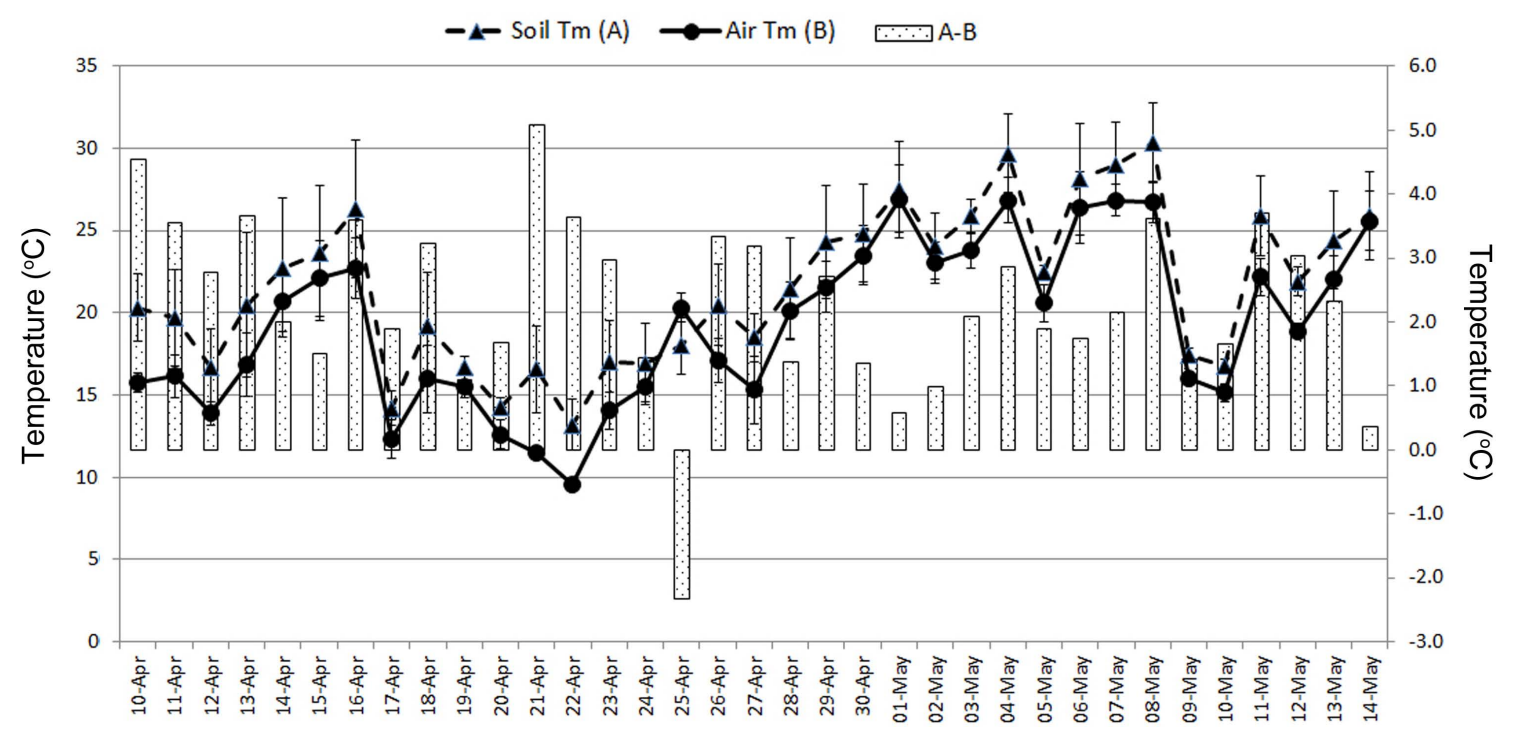

Fig. 4. Monitoring of soil and air temperature of organic potato cultivation field during the spring season in Wonju. 


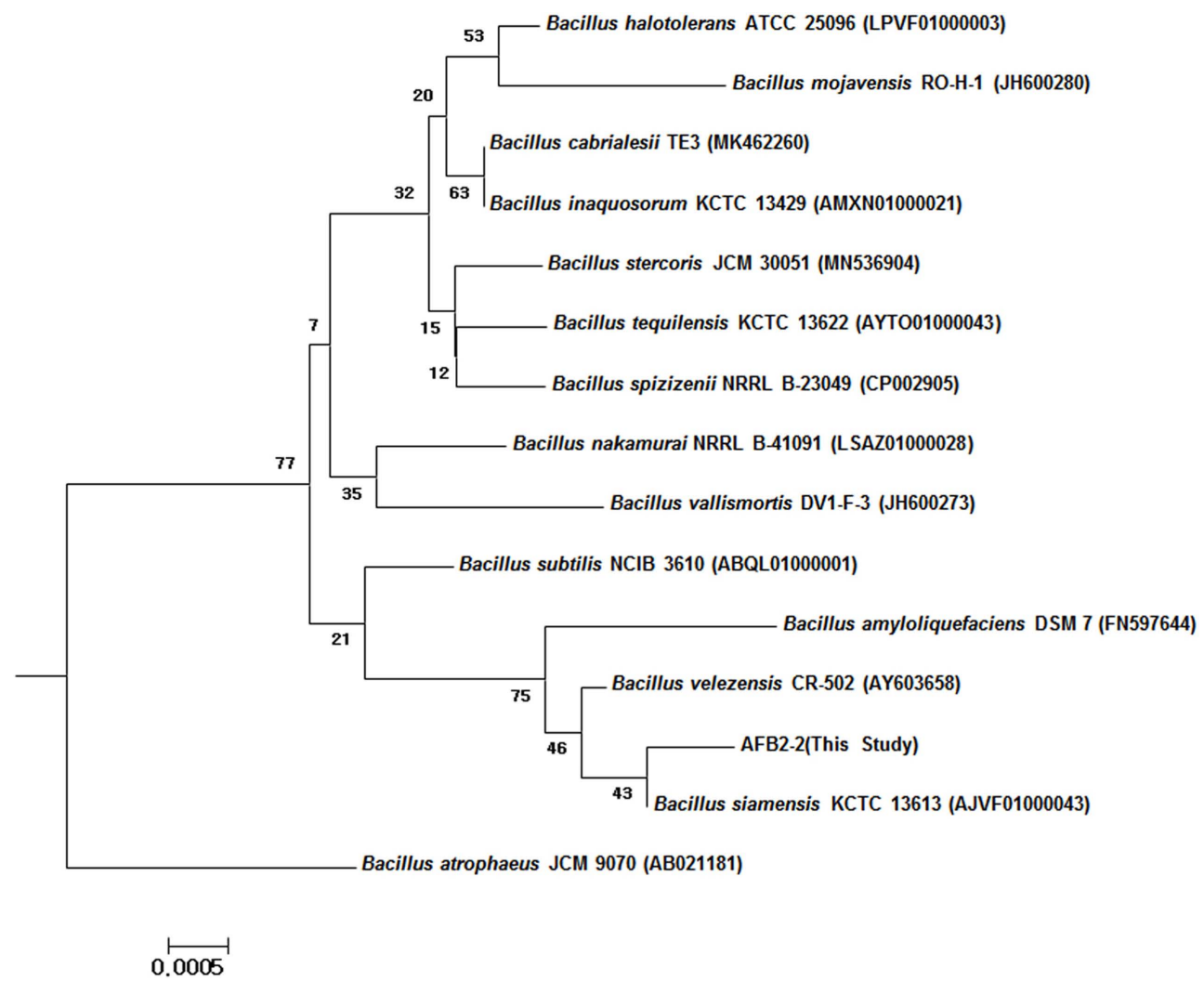

Fig. 5. Base sequence comparison analysis of the 16S rRNA gene sequence for Bacillus sp. AFB2-2 and the related Bacillus bacteria. The tree was generated using Neighbor-joining. Scale bar $=0.0005$ substitutions per nucleotide.

2 had a rough and wrinkled white color on the surface of the colony, and the form was a gram-positive bacterium of Bacillus in Table 2. As a result of identification of the strain through the study of sugar availability using the API 50 CHB system (Table 2), it was identified as Bacillus velezensis (synonym of $B$. amyloliquefaciens) (data not shown). For more accurate identification, after determining the 16S rRNA gene sequence of the isolated strain $(1.5 \mathrm{~kb})$ was amplified from purified genomic DNA of the AFB22 strain. The amplified nucleotide sequence of $1,492 \mathrm{bp}$ was sequenced and analyzed. The obtained sequences were searched against the NCBI GenBank database. Bacillus siamensis strain KCTC 13613, Bacillus velezensis strain CR-502, and Bacillus amyloliquefaciens strain DSM7 were found to have a similarity of $99.7 \%, 99.7 \%$, and $99.5 \%$, respectively (Fig. 5). As shown, the isolated strain was named B. velezensis AFB2-2, and the base sequence of the $16 \mathrm{~S}$ rRNA gene was registered in GenBank.

Detection of secondary metabolite biosynthesis genes of B. velezensis AFB2-2 strain. B. velezensis AFB2-2 strain showed prominent antibacterial activity against various plant pathogens. PCR-based detection of biosynthetic genes revealed that it harbors three secondary metabolite

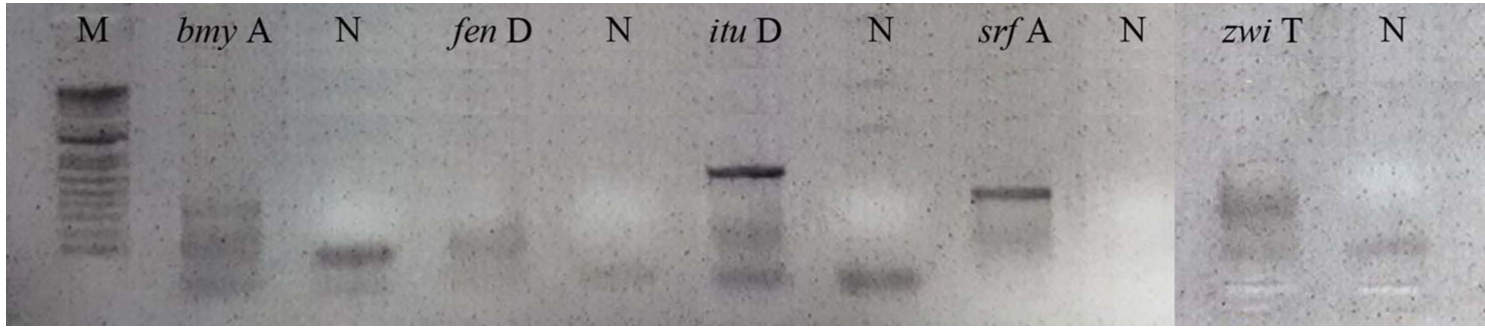

Fig. 6. PCR detection of biosynthetic genes, bacillomycin D (bmyA), fengycin (fenD), iturin A (ituA), surfactin $(s r f A)$, and zwittermicin A (zwiA) Bacillus velezensis AFB2-2. N, negative control; M, molecular marker (100-bp DNA ladder). 
biosynthesis genes, namely, bacillomycin D (bmyA, 875 bp), iturin A (ituA, $647 \mathrm{bp})$, and surfactin ( $\operatorname{srfA}, 441 \mathrm{bp}$ ) (Fig. 6). However, genes related to fengycin and zwittermicin production were not detected (Fig. 6).

\section{Discussion}

Recently, interest in organic agriculture has been growing considerably as the demand for environmentally safe agricultural products has rapidly increased. However, research on eco-friendly agricultural technologies is needed to prevent the damage from pests and diseases for increasing the yield.

The incidence and progress of the disease largely depend on climatic conditions around the fields (Miller et al., 1998). Potato leaves in conventional farming fields remain healthy for 5 weeks after the appearance of the first symptom, as fungicides are applied four times on an average to control the disease (Ryu et al., 2005). However, potato late blight is not easy to control and manage by organic/biological means. Organic farmers should employ multiple strategies available to reduce late blight risk in host crops (Ryu et al., 2005).

The morphological and biological characteristics of AFB2-2, characterized in the present work, were similar to the $B$. velezensis described by Kim et al. (2017) and Chen et al. (2018). Our morphological identification was confirmed by amplification and sequencing of a partial fragment of the 16S rRNA region (Smibert and Krieg, 1994).

Recently, Chun et al. (2019) and Jin et al. (2018), Larabinose, D-xylose, and D-mannose in a study comparing the biochemical properties of the $B$. amyloliqefaciens group and the $B$. siamensis group similar to the $B$. velezensis group. And it was reported that there is a difference in the use of D-trehalose. In particular, it suggests that the difference can be distinguished from the $B$. amyloliqefaciens group, which shows the most similarity in $16 \mathrm{~S}$ rRNA analysis.

In this study, as a result of $16 \mathrm{~S}$ rRNA analysis of the AFB 2-2 strain, it was found that the $B$. siamensis group and the $B$. amyloliqefaciens group were closest to each other. However, the assay results for biochemical availability using the API50CHB were reported by Chun et al. (2019) and Jin et al. (2018), it is judged to show higher similarity to the Bacillus velezensis group in the use of L-arabinose, D-xylose, D-mannose and D-trehalose. Therefore, we identified the AFB 2-2 strain as B. velezensis AFB 2-2 based on the overall results from the morphological, biochemical test and molecular data.

Bacillus, Pseudomonas, and other microorganisms have been extensively studied for their ability to solubilize nutrients, biocontrol potential, and plant growth-promoting abilities in all crop production systems. However, successful deployment of these organisms in ecosystems under stress depends on their ability to withstand and proliferate under adverse environments such as heat, salinity, heavy metal toxicity, and so forth (Praveen Kumar et al., 2014; Lucy et al., 2004).

Several studies have emphasized the use of beneficial microorganisms, which can tolerate heat stress and augment the growth and productivity of crop plants (Abd ElDaim et al., 2014; Ali et al., 2009, 2011; Khan et al., 2020; Park et al, 2017; Srivastava et al., 2008). In this study, $B$. velezensis AFB2-2 was a strain capable of growing at a high temperature of $50^{\circ} \mathrm{C}$, and its stable culture was possible at $37^{\circ} \mathrm{C}$ in a liquid medium.

Salt stress tolerance is an important property of saprophytes and competitiveness among rhizobial isolates. Therefore, it was observed that some of the salt-tolerant isolates might have good saprophytic and competitive abilities to perform well in the rhizosphere of soil (Praveen Kumar et al., 2014). The salt-tolerant microbes were domesticated to tolerate higher concentrations of $\mathrm{NaCl}$, which can play a biological role in high salt stress in field conditions.

Salt-tolerant bacteria can enhance the ability of plants to withstand salt stress. The bacterium has a special cell membrane and cell wall structure, which can effectively prevent $\mathrm{Na}^{+}$from entering the cell, and maintain a low salt concentration in the cell. Thus, it can play a greater role in promoting the growth and the cultivation of salt-tolerant plants (Hussein and Joo, 2018; Masmoudi et al., 2019; Siddikee et al., 2010; Wang et al., 2021).

Soil salt accumulation has been steadily increasing over the past 10 years and is pointed out as a major inhibitor to crop growth along with soil heavy metals and pathogens (Hussein and Joo, 2018). The AFB2-2 strain could be cultured at a concentration of $7.5 \%$ of $\mathrm{NaCl}$ and it might potentially survive in soil with a high salt concentration.

Potato (Solanum tuberosum L.) is the third most important food crop consumed in the world after rice and wheat. Late blight, caused by the oomycete pathogen $P$. infestans, is considered the most devastating disease in the cultivation of potato (Kamoun et al., 2015).

In total, 149 types of microbial pesticides have been registered worldwide and used against pests and diseases. Bacillus subtilis QST 713 (RhapsodyR, SerenadeR) and Bacillus pumilus QST 2808 (Sonata R) have been developed for disease control and used as eco-friendly biological pesticides in Korea and many other countries (Cawoy et 
al., 2011; Copping, 2004).

In this study, B. velezensis (AFB2-2 strain) could suppress potato late blight caused by $P$. infestans in the greenhouse and natural field conditions. The $B$. velezensis (AFB2-2 strain) showed substantial growth inhibitory effect against the mycelia of seven important plant pathogens including $P$. infestans, and possesses three secondary metabolite biosynthesis genes namely, bacillomycin $\mathrm{D}$, iturin $\mathrm{A}$, and surfactin.

Secondary metabolites produced by Bacillus strains, related to plant disease control are cyclic lipopeptides (bacillomycin D, fengycin, iturin, surfactin), siderophore (bacillibactin), polyketides (bacillaene, difficidin, and macrolactin), a dipeptide (basilysin), acetoin, 2, 3-butandiol, etc. (Lee et al., 2012; Ramarathnam et al., 2007). These can aid in the inhibition of mycelial growth or spore germination in fungal pathogens, induction of resistance, and formation of biofilms to prevent plant diseases. It can be used in farms as an eco-friendly control strategy in organic potato cultivation.

Bacillus strains produce various secondary metabolites owing to the presence of biosynthetic genes. Genes for synthesis of bacillomycin D and fengycin were found to be present in the GH1-13 strain, which produced the relevant antibiotics (Kim et al., 2016). Kim et al. (2012) reported that Bacillus amyloliquifaciens GR4-5 strain harbored the fengycin biosynthesis gene in addition to the bacilycin biosynthesis gene, and their antibacterial activity was also confirmed. Moreover, Kim et al. (2016) reported that the GH1-13 strain possessed four types of genes: bacillomycin D (875 bp), bacilycin (749 bp), fengycin (964 bp), iturin (647 bp), and surfactin (441 bp). PCR was performed using gene-specific primers for detecting, ituA (iturin A), srfA (surfactin), and zwiA (zwittermicin A).

In conclusion, although potato is one of the most important vegetable crops in Korea and across the world, its susceptibility to diseases like late blight caused by Phytophthora infestans makes its cultivation challenging. In our study, Bacillus velezensis AFB2-2 strain, which has excellent antifungal activity against major plant pathogens, was characterized for its mycelial growth inhibition and identified by molecular analysis. This strain was also screened for the presence of cyclic lipopeptide synthesis genes and evaluated for its efficacy in controlling potato late blight in an organic potato field. We found that the AFB2-2 strain is a gram-positive spore-forming bacterium with peritrichous flagella and motility that can utilize 20 types of carbon sources, with the optimum growth temperature at $37^{\circ} \mathrm{C}$. Its maximum salt concentration tolerance is $7.5 \% \mathrm{NaCl}$. This strain could inhibit the mycelial growth of seven plant pathogens after 7 days. After 42 days of AFB22 treatment, the disease occurrence in AFB2-2 treated potatoes was $13.3 \%$ or less. This strain was found to harbor the biosynthetic genes for bacillomycin $\mathrm{D}$, iturin, and surfactin. We believe that the present findings on the characterization of the AFB2-2 strain can be used to develop an effective microbial agent for inhibiting the growth of fungal and bacterial pathogens against various crops through organic agriculture.

Although the late blight disease is an important fact in eco-friendly potato cultivation in Korea. Potato late blight resulted in annual yield losses of several billion dollars, in addition to the negative effects on the environment of frequent use of fungicides. For these issues, environmental products increasingly appear to be a significant portion of the pesticide market. Recently, it is highly dependent on the use of eco-friendly agricultural materials and the developments of biological control results are low. Biological control is an alternative technique to synthetic chemical fungicides in control of plant diseases, in order to create a more sustainable agricultural system

\section{Conflicts of Interest}

No potential conflict of interest relevant to this article was reported.

\section{Acknowledgments}

This study was carried out with the support of the Research Program for Agricultural Science \& Technology Development (Project No. PJ01587602) funded by the Rural Development Administration in the Republic of Korea in 2021.

\section{References}

Abd El-Daim, I. A., Bejai, S. and Meijer, J. 2014. Improved heat stress tolerance of wheat seedlings by bacterial seed treatment. Plant Soil 379:337-350.

Ali, S. Z., Sandhya, V., Grover, M., Kishore, N., Rao, L. V. and Venkateswarlu, B. 2009. Pseudomonas sp. strain AKM-P6 enhances tolerance of sorghum seedlings to elevated temperatures. Biol. Fertil. Soils. 46:45-55.

Ali, S. Z., Sandhya, V., Grover, M., Linga, V. R. and Bandi, V. 2011. Effect of inoculation with a thermotolerant plant growth promoting Pseudomonas putida strain AKMP7 on growth of wheat (Triticum spp.) under heat stress. J. Plant Interact. 6:239-246.

Asaturova, A., Shternshis, M., Tsvetkova, V., Shpatova, T., Maslennikova, V., Zhevnova, N. and Homyak, A. 2021. Biological control of important fungal diseases of potato and 
raspberry by two Bacillus velezensis strains. PeerJ 9:e11578. Athukorala, S. N. P., Fernando, W. G. D. and Rashid, K. Y. 2009. Identification of antifungal antibiotics of Bacillus species isolated from different microhabitats using polymerase chain reaction and MALDI-TOF mass spectrometry. Can. J. Microbiol. 55:1021-1032.

Buck, J. D. 1982. Nonstaining (KOH) method for determination of gram reactions of marine bacteria. Appl. Environ. Microbiol. 44:992-993.

Cawoy, H., Bettiol, W., Fickers, P. and Ongena, M. 2011. Bacillus-based biological control of plant diseases. In: Pesticides in the modern world: pesticides use and management, ed. by M. Stoytcheva, pp. 273-302. InTech, Rijeka, Croatia.

Chen, L., Gu, W., Xu, H.-Y., Yang, G.-L., Shan, X.-F., Chen, G., Wang, C.-F. and Qian, A.-D. 2018. Complete genome sequence of Bacillus velezensis 157 isolated from Eucommia ulmoides with pathogenic bacteria inhibiting and lignocellulolytic enzymes production by SSF. 3 Biotech 8:114.

Chet, I. and Inbar, J. 1994. Biological control of fungal pathogens. Appl. Biochem. Biotechnol. 48:37-43.

Choi, K. S. 2007. Field evaluation of fungicides for controlling potato late blight and monitoring of fungicide resistance. Master thesis. Gangneung-Wonju National University, Gangneung, Korea (in Korean).

Chun, B. H., Kim, K. H., Jeong, S. E. and Jeon, C. O. 2019. Genomic and metabolic features of the Bacillus amyloliquefaciens group- B. amyloliquefaciens, B. velezensis, and B. siamensis- revealed by pan-genome analysis. Food Microbiol. 77:146-157.

Chycoski, C. I. and Punja, Z. K. 1996. Characteristics of populations of Phytophthora infestans from potato in British Columbia and other regions of Canada during 1993 to 1995. Plant Dis. 80:579-589.

Cohen, Y., Gisu, U. and Mosinger, E. 1991. Systemic resistance of potato plants against Phytophthora infestans induced by unsaturated fatty acids. Physiol. Mol. Plant Pathol. 38:255263.

Cohen, Y. and Reuveni, M. 1983. Occurrence of metalaxylresistant isolates of Phytophthora infestans in potato fields in Israel. Phytopathology 73:925-927.

Copping, L. G. 2004. The manual of biocontrol agents. 4th ed. British Crop Protection Council, Alton, UK. 702 pp.

Desjardins, A. E., McCormick, S. P. and Corsini, D. L. 1995. Diversity of sesquiterpenes in 46 potato cultivars and breeding selections. J. Agric. Food Chem. 43:2267-2272.

Dinu, S., Boiu-Sicuia, O.-A. and Constantinescu, F. 2019. Influence of Bacillus Spp. based bioproducts on potato plant growth and control of Rhizoctonia solani. Bull. Univ. Agric. Sci. Vet. Med. Cluj-Napoca, Anim. Sci. Biotechnol. 76:29-34.

Dowley, L. J. and O'sullivan, E. 1981. Metalaxyl-resistant strains of Phytophthora infestans (Mont.) de bary in ireland. Potato Res. 34:417-421.

El-Naggar, M. A., Abouleid, H. Z., El-Deeb, H. M., Abd-ElKareem, F. and Elshahawy, I. E. 2016. Biological control of potato late blight by means of induction systemic resistance and antagonism. Res. J. Pharm. Biol. Chem. Sci. 7:1338-1348.

Elad, Y. and Kapat, A. 1999. The role of Trichoderma harzianum protease in the biocontrol of Botrytis cinerea. Eur. J. Plant Pathol. 105:177-189.

Estrella, F. S., Elorrieta, M. A., Vargas, G. C., López, M. J. and Moreno, J. 2001. Selective isolation of antagonist microorganisms of Fusarium oxysporum f. sp. melonis. Biol. Control Plant Pathol. 24:109-112.

Felsenstein, J. 1985. Confidence limits on phylogenies: an approach using the bootstrap. Evolution 39:783-791.

Folman, L. B., De Klein, M. J. E. M., Postma, J. and van Veen, J. A. 2004. Production of antifungal compounds by Lysobacter enzymogenes isolate $3.1 \mathrm{~T} 8$ under different conditions in relation to its efficacy as a biocontrol agent of Pythium aphanidermatum in cucumber. Biol. Control 31:145-154.

Fravel, D. R. 2005. Commercialization and implementation of biocontrol. Annu. Rev. Phytopathol. 43:337-359.

Fry, W. E., Goodwin, S. B., Matuszak, J. M., Spielman, L. J., Milgroom, M. G. and Drenth, A. 1992. Population genetics and intercontinental migrations of Phytophthora infestans. Annu. Rev. Phytopathol. 30:107-129.

Giddings, N. J. and Berg, A. 1919. A comparison of the late blights of tomato and potato. Phytopathology 9:209-210.

Hahm, Y. I., Hahn, B. H. and Franckowiak, J. D. 1978. Forecasting late blight of potatoes at the alpine area in Korea. Korean J. Plant Prot. 17:81-87.

Halebian, S., Harris, B., Finegold, S. M. and Rolfe, R. D. 1981. Rapid method that aids in distinguishing Gram-positive from Gram-negative anaerobic bacteria. J. Clin. Microbiol. 13:444448.

Hartmann, M., Berditsch, M., Hawecker, J., Ardakani, M. F., Gerthsen, D. and Ulrich, A. S. 2010. Damage of the bacterial cell envelope by antimicrobial peptides gramicidin $\mathrm{S}$ and PGLa as revealed by transmission and scanning electron microscopy. Antimicrob. Agents Chemother. 54:3132-3142.

Hussein, K. A. and Joo, J. H. 2018. Plant growth-promoting rhizobacteria improved salinity tolerance of Lactuca sativa and Raphanus sativus. J. Microbiol. Biotechnol. 28:938-945.

Hwang, J. Y., Shim, C.-K., Ryu, K.-Y., Choi, D.-H. and Jee, H.J. 2006. Selection of Brevibacillus brevis B23 and Bacillus stearothermophilus B42 as biological control agents against sclerotinia rot of lettuce. Res. Plant Dis. 12:254-259 (in Korean).

International Potato Center. 2004. Annual report. Late blight new development. International Potato Center, Lima, Peru. pp. 9-13.

Jin, S.-R., Lee H.-M., Nam K.-W. and Park, K. 2018. Biological control of white strain symptom on grape fruit by Bacillus velezensis MWS28. Korean J. Pestic. Sci. 22:345-355.

Kamoun, S., Furzer, O., Jones, J. D., Judelson, H. S., Ali, G. S., Dalio, R. J., Roy, S. G., Schena, L., Zambounis, A., Panabières, F., Cahill, D., Ruocco, M., Figueiredo, A., Chen, X. R., Hulvey, J., Stam, R., Lamour, K., Gijzen, M., Tyler, B. 
M., Grünwald, N. J., Mukhtar, M. S., Tomé, D. F., Tör, M., Van Den Ackerveken, G., McDowell, J., Daayf, F., Fry, W. E., Lindqvist-Kreuze, H., Meijer, H. J., Petre, B., Ristaino, J., Yoshida, K., Birch, P. R. and Govers, F. 2015. The top 10 oomycete pathogens in molecular plant pathology. Mol. Plant Pathol. 16:413-434.

Kang, S. Y., Kim, C. W. and Jeon, Y. C. 2013. Disease suppression on late blight in potato tissue culture by Burkholderia gladioli TRK2-2 or DL-3-amino butyric acid. J. Asian Agric. Biotechnol. 29:1-7.

Kerkeni, A., Daami-Remadi, M., Tarchoun, N. and Khedher, M. B. 2007. In vitro and in vivo suppression of Fusaruim oxysporum f. sp. radicis-lycopersici the causal agent of Fusarium crown and root rot of tomato by some compost fungi. Int. J. Agric. Res. 2:1022-1029.

Khan, M. A., Asaf, S., Khan, A. L., Jan, R., Kang, S.-M., Kim, K.-M. and Lee, I.-J. 2020. Thermotolerance effect of plant growth-promoting Bacillus cereus SA1 on soybean during heat stress. BMC Microbiol. 20:175.

Kim, B.-S., Choi, J.-H., Chun, W.-H., Ryu, K-Y., Hahm, Y.-I. and Lee, Y.-S. 2000. Mating type and metalaxyl sensitivity of Phytophthora infestans isolated from Kangwon area in Korea. Korean J. Pestic. Sci. 4:59-63 (in Korean).

Kim, B.-Y., Ahn, J.-H., Weon, H.-Y., Song, J., Kim, S.-I. and Kim, W.-G. 2012. Isolation and characterization of Bacillus species possessing antifungal activity against ginseng root rot pathogens. Korean J. Pestic. Sci. 16:357-363 (in Korean).

Kim, S. Y., Lee, S. Y., Weon, H.-Y., Sang, M. K. and Song, J. 2017. Complete genome sequence of Bacillus velezensis M75, a biocontrol agent against fungal plant pathogens, isolated from cotton waste. J. Biotechnol. 241:112-125.

Kim, S. Y., Sang, M. K., Weon, H.-Y., Jeon, Y.-A., Ryoo, J. H. and Song, J. 2016. Characterization of multifunctional Bacillus sp. GH1-13. Korean J. Pestic. Sci. 20:189-196 (in Korean).

Kimura, M. 1980. A simple method for estimating evolutionary rates of base substitutions through comparative studies of nucleotide sequences. J. Mol. Evol. 16:111-120.

Kirk, W., Wharton, P., Hammerschmidt, R., Abu-el Samen, F. and Douches, D. 2004. Late blight. URL https://www.canr.msu. edu/resources/michigan_potato_diseases_late_blight_e2945 [18 March 2010].

Kumar, S., Stecher, G. and Tamura, K. 2016. MEGA7: molecular evolutionary genetics analysis version 7.0 for bigger datasets. Mol. Biol. Evol. 33:1870-1874.

Lamsal, K., Kim, S. W., Kim, Y. S. and Lee, Y. S. 2013. Biocontrol of late blight and plant growth promotion in tomato using rhizobacterial isolates. J. Microbiol. Biotechnol. 23:897-904.

Latijnhouwers, M., Ligterink, W., Vleeshouwers, V. G. A. A., van West, P. and Govers, F. 2004. A G $\alpha$ - subunit controls zoospore motility and virulence in the potato late blight pathogen Phytophthora infestans. Mol. Microbiol. 51:925-936.

Lee, S.-Y., Kim, B.-Y., Ahn, J.-H., Song, J., Seol, Y.-J., Kim, W.G. and Weon, H.-Y. 2012. Draft genome sequence of the biocontrol bacterium Bacillus amyloliquefaciens strain M27. J. Bacteriol. 194:6934-6945.

Lee, W. H., So, M. S. and Choi, I. Y. 1994. Fungicide-resistance and mating type of Phytophthora infestans causing potato late blight. Korean J. Plant Pathol. 10:192-196 (in Korean).

Lucy, M., Reed, E. and Glick, B. R. 2004. Applications of free living plant growth-promoting rhizobacteria. Antonie Van Leeuwenhoek 86:1-25.

Lynch, D. H., Halberg, N. and Bhatta, G. D. 2012. Environmental impact of organic agriculture in temperate regions. CAB Rev. 7:010.

Masmoudi, F., Abdelmalek, N., Tounsi, S., Dunlap, C. A. and Trigui, M. 2019. Abiotic stress resistance, plant growth promotion and antifungal potential of halotolerant bacteria from a Tunisian solar saltern. Microbiol. Res. 229:126331.

Miller, J. S., Johnson, D. A. and Hamm, P. B. 1998. Aggressiveness of isolates of Phytophthora infestans from the Columbia Basin of Washington and Oregon. Phytopatholgy 88:190-197.

Novy, R. G., Love, S. L., Corsini, D. L., Pavek, J. J., Whitworth, J. L., Mosley, A. R., James, S. R., Hane, D. C., Shock, C. C., Rykbost, K. A., Brown, C. R., Thornton, R. E., Knowles, N. R., Pavek, M. J., Olsen, N. and Inglis, D. A. 2006. Defender: a high-yielding, processing potato cultivar with foliar and tuber resistance to late blight. Am. J. Potato Res. 83:9-19.

Ongena, M. and Jacques, P. 2008. Bacillus lipopeptides: versatile weapons for plant disease biocontrol. Trends Microbiol. 16:115-125.

Park, K.-H., Ryu, K.-Y., Yun, J.-C., Jeong, K.-S., Kim, J.-S., Kwon, M., Kim, B.-S. and Cha, B.-J. 2010. Changes of mating type distribution and fungicide-resistance of Phytophthora infestans collected from Gangwon Province. Res. Plant Dis. 16:274-278 (in Korean).

Park, Y. E., Cho, H. M., Cho, J.-H., Cho, K. S., Kim, H. J. and Landeo, J. 2011. Evaluation of late blight resistance and agronomic characteristics of short-day adapted potato germplasm. Korean J. Hortic. Sci. Technol. 29:474-481 (in Korean).

Park, Y.-G., Mun, B.-G., Kang, S.-M., Hussain, A., Shahzad, R., Seo, C.-W., Kim, A.-Y., Lee, S.-U., Oh, K. Y., Lee, D. Y., Lee, I.-J. and Yun, B.-W. 2017. Bacillus aryabhattai SRB02 tolerates oxidative and nitrosative stress and promotes the growth of soybean by modulating the production of phytohormones. PLoS ONE 12:e0173203.

Praveen Kumar, G., Mir Hassan Ahmed, S. K., Desai, S., Leo Daniel Amalraj, E. and Rasul, A. 2014. In vitro screening for abiotic stress tolerance in potent biocontrol and plant growth promoting strains of Pseudomonas and Bacillus spp. Int. J. Bacteriol. 2014:195946.

Quimby, P. C., King, L. R. and Grey, W. E. 2002. Biological control as a means of enhancing the sustainability of crop/land management systems. Agric. Ecosyst. Environ. 88:147-152.

Ramarathnam, R., Bo, S., Chen, Y., Fernando, W. G. D., Xuewen, G. and de Kievit, T. 2007. Molecular and biochemical detection of fengycin- and bacillomycin D-producing Bacillus spp., antagonistic to fungal pathogens of canola and wheat. 
Can. J. Microbiol. 53:901-911.

Ryu, K.-Y., Jee, H.-J., Choi, D.-H., Cheon, J.-U., Kim, J.-T. and Kim, B.-S. 2005. Disease progress and yield loss of potato late blight caused by Pntytophthora Infestans in organic farming fields. Res. Plant Dis. 11:122-127 (in Korean).

Saitou, N. and Nei, M. 1987. The neighbor-joining method: a new method for reconstructing phylogenetic trees. Mol. Biol. Evol. 4:406-425.

Sambrook, J., Fritsch, E. F. and Maniatis, T. 1989. Molecular cloning: a laboratory manual. 2nd ed. Cold Spring Harbor Laboratory, New York, NY, USA.

Shim, C.-K., Kim, M.-J., Kim, Y.-K., Jee, H.-J., Park, J.-H., Hong, S.-J., Han, E.-J. and Kim, S.-C. 2015. Estimation of the chitinolytic and antifungal activity of Streptomyces sp. CA-23 and AA-65 isolates isolated from waste mushroom media. Korean J. Pestic. Sci. 19:402-410 (in Korean).

Siddikee, M. A., Chauhan, P. S., Anandham, R., Han, G.-H. and Sa, T. 2010. Isolation, characterization, and use for plant growth promotion under salt stress, of ACC deaminaseproducing halotolerant bacteria derived from coastal soil. $J$. Microbiol. Biotechnol. 20:1577-1584.

Smibert, R. M. and Krieg, N. R. 1994. Phenotypic characterization. In: Methods for general and molecular bacteriology, eds. by P. Gerhardt, R. G. E. Murray, W. A. Woods and N. R. Krieg, pp. 607-654. American Society for Microbiology,
Washington, DC, USA.

Srivastava, S., Yadav, A., Seem, K., Mishra, S., Chaudhary, V. and Nautiyal, C. S. 2008. Effect of high temperature on Pseudomonas putida NBRI0987 biofilm formation and expression of stress sigma factor RpoS. Curr. Microbiol. 56:453-457.

Thompson, J. D., Higgins, D. G. and Gibson, T. J. 1994. CLUSTAL W: improving the sensitivity of progressive multiple sequence alignment through sequence weighting, positionspecific gap penalties and weight matrix choice. Nucleic Acids Res. 22:4673-4680.

Wang, R., Wang, C., Feng, Q., Liou, R.-M. and Lin, Y.-F. 2021. Biological inoculant of salt-tolerant bacteria for plant growth stimulation under different saline soil conditions. J. Microbiol. Biotechnol. 31:398-407.

Yao, Y., Li, Y., Chen, Z., Zheng, B., Zhang, L., Niu, B., Meng, J., Li, A., Zhang, J. and Wang, Q. 2016. Biological control of potato late blight using isolates of Trichoderma. Am. J. Potato Res. 93:33-42.

Yeo, S.-H., Yook, Y.-M. and Kim, H.-S. 2009. Isolation and characterization of plant growth promoting rhizobacterium Bacillus subtilis YK-5 from soil. KSBB J. 24:334-340 (in Korean).

Zhang, X.-Z., Ryu, K.-Y., Kim, J.-S., Cheon, J.-U. and Kim, B.-S. 2005. Changes in the sensitivity to metalaxyl, dimethomorph and ethaboxam of Phytophthora infestans in Korea. Plant Pathol. J. 21:33-38. 